\section{Trust the wildlife volunteers}

SIR - The amendment to prohibit the US National Biological Survey (NBS) from accepting the services of volunteers (Nature 367, 400; 1994) was supported by two arguments in the House of Representatives (Washington Post, 25 December 1993). They were that volunteers are incompetent and that they are biased. That is not the European experience.

I write as director of the British Trust for Ornithology and chairman of the European Bird Census Council. In Britain and Ireland, the volunteer network has made invaluable contributions to the assessment of wildlife resources. This is especially true in ornithology, where we have had two distributional atlases of breeding birds at a 20 -year interval (with an atlas of winter distributions intercalated), annual population monitoring of most common and many rare birds, and continuing assessment of breeding success and survival. From this information, through an integrated programme of analysis and through related studies on how birds use their habitats and how they are affected by management practices, we can identify species, guilds and habitats that seem to be in trouble and the possible causes of the problems. This in turn can lead to more specific and intensive studies, by volunteers or professionals, to illuminate the causes further and to provide the basis for sound conservation action.

This volunteer-based work is accepted as a reliable foundation for policy-making and planning by government, by conservation bodies and by the agricultural, forestry and other industries. The competence of the amateur birdwatchers is recognized to be as high as that of professionals. Bias is not an issue, not only because there is no empirical evidence for such bias but also because the participants recognize that biased evidence would not allow conservationists themselves to develop sound policies. (In addition, it may be significant that most of the work is not organized by bodies that are also involved in conservation campaigning.)

Although Britain may have, perhaps through no more than historical accident, the best developed and most highly integrated volunteer-based schemes for ornithological monitoring, there are similar programmes in other European countries. Indeed, the European Bird Census Council is promoting the use of such schemes as ways of monitoring the health of the wildlife environment throughout Europe.

Programmes to use volunteers for wildlife assessment are not as developed or as integrated in North America as in Britain and Ireland. The establishment of the NBS represents an opportunity for a great leap forward. If the opportunity is to be seized, the key message to be taken on board, by politicians and by professional scientists alike, is "Trust the volunteers". Jeremy J. D. Greenwood

The Nunnery,

Thetford, Norfolk IP24 2PU, UK

\section{Fraunhofer funds}

SIR - We appreciate your interest in the Fraunhofer Institutes. Unfortunately, a passage in Alison Abbott's article (Nature 365,481 ; 1993) is open to misinterpretation. She reports that the German Federal Research Minister, Dr Paul Krüger, had said to me privately - in contradiction of his public statements - that he would like to cut the funds dedicated to fundamental research from 40 per cent to one-third, in favour of the Fraunhofer-Gesellschaft. On the contrary, the minister stressed the positive value of application-oriented research, without mentioning any redistribution of funds. And I myself pointed out in my conversation with Abbott that it would be desirable for more to be done for applied research, which is the very basis of innovation, and thus serves to enhance the competitiveness of German enterprise within international markets. In view of the meagre funds available, the question of their appropriate distribution is paramount.

Hans-Jürgen Warnecke

(President)

Fraunhofer Society,

Leonrodstrasse 54 ,

D-80636 München, Germany

\section{Smallpox bargain}

SIR - Your leading article "End of the line for smallpox virus?" (Nature 366, 711; 1993) was responsible and balanced but I wish to correct the statement that the eradication of the disease was costly. According to a detailed study to ascertain all the international costs, including estimates to account for the services of the Peace Corps and Oxfam volunteers, and the contributions by several organizations of vaccines and vehicles, the total was just under $\$ 100$ million. In contrast, the cost to the United States in 1969 for smallpox vaccination, complications of vaccination, quarantine and so on amounted to $\$ 150$ million - for one year alone.

These comparisons show that smallpox was eradicated, by an international effort, for a cost equivalent to two-thirds of the expenditure by the United States in eight months for smallpox control. This seems to me to be a bargain. The efforts by the World Health Organization and those organizing the programme, Drs Henderson, Fenner and Arita, deserve more than the somewhat snide remarks about the contributions of this often-criticized body. To eradicate a major disease deserves unreserved commendation and was indeed recognized by the award of the Japan Prize to several of the principals involved in the programme.

\section{Fred Brown}

\section{US Department of Agriculture,}

Plum Island Animal Disease Center, POBox 848 .

Greenport, New York 11944-0848, USA

\section{Avoiding bends}

SIR - Daedalus has expressed the idea (Nature 365, 18 \& 112; 1993) that seals and dolphins must have evolved an inhibitor against air bubbles, leading to the considerable resources of DREADCO's research team being channelled into the search for the responsible protein. However, the members of the research team of their corporate adversaries, DREAMCO, were aware that such a search was in vain. They know that seals and dolphins avoid the bends by denying nitrogen the opportunity to become supersaturated in the blood. Unlike man, dolphins and seals do not breathe while submerged and forcibly exhale before a deep descent. Hence there is no nitrogen available to supersaturate the blood.

Seals and dolphins are able to stay submerged for great lengths of time because of large blood volumes and superb oxygen-carrying capacity. The researchers at DREAMCO are now working to impart this oxygen-carrying capacity to humans. The genetic code responsible for the production of haemoglobin is being spliced into bacterial cells. The 'super oxygen' bacteria are then ingested in a similar manner to an asthmatic spray. With the help of the bacteria, the code makes its way into blood cells and begins to produce vast amounts of oxygencarrying haemoglobin. These infected cells are unable to reproduce and eventually die, ensuring a continuing market for DREAMCO's Aerobic Spray.

The market for such a product would appear to be enormous. The benefit for sporting people is clear. Other benefits would include a decrease in the number of drownings, due to the ability of a user to forgo fresh oxygen for up to five times as long. Indeed, some believe DREAMCO may already be successfully trying out the spray with the company-owned professional cycling team which has won every event entered over recent weeks.

\section{Vincent Craig}

Department of Chemistry,

Australian National University,

Canberra, ACT 0200 ,

Australia 